\title{
Electronic Business Maturity in Portuguese SME and Large Enterprises
}

\author{
Elisabete Paulo Morais ${ }^{1}$, Sónia Sousa Santos ${ }^{2}$, \\ and Ramiro Moreira Gonçalves². \\ ${ }^{1}$ Polytechnic Institute of Bragança, Mirandela, Portugal, \\ ${ }^{2}$ University of Trás-os-Montes and Alto Douro, Vila Real, Portugal
}

\begin{abstract}
Since the introduction of computer technology into organizations in the 1960s, there have been numerous attempts to develop models of Information Systems/Information Technology (IS/IT) maturity. The maturity models are based on the premise that the planning process, development or adoption, use and management of IS/IT organizations, evolves through a learning process that can move through stages of maturity. If these stages (and their associated features) can be identified, could then be used to develop a plan for the IS and provide guidelines for action for the orderly progression through several stages from the current culture of the organization. This work focuses the e-business maturity stages of Portuguese SMEs (Small and Medium Enterprises) and large enterprises. Our goal is to identify in which ebusiness maturity stage they are and explore the relationship between their e-business maturity and the associated constrains to e-business evolution (previously identified in an exploratory study).
\end{abstract}

Keywords: e-business; maturity models; stages of growth; constraints

\section{Introduction}

The European Commission has long emphasized the importance of ICT (Information Technology and Communication) for a thriving European economy. Effective use of ICT by businesses is a crucial factor of success for the competitiveness, innovation and growth. We need a thorough analysis of its strategic potential to create new business models, to influence the chains value and increase the efficiency of processes. Large companies are exploiting the advantages offered by ICT and e-business. Regarding the small businesses, or they follow the same path or they risk be being excluded from digital supply chains. It is clear that ICT and ebusiness are important for a wide range of policy area, including innovation, standards, policies for SMEs (Small and Medium Enterprises) and Industrial policies (European Commission, 2008).

E-business offering opportunities and having great potential to provide competitive advantage by lowering cost, increases effectiveness and cohesion between the company and its business partners. As an organization enters the world of e-business, there are a range of issues to think through as well as the 
challenges and opportunities presented by e-business (Prananto et al., 2004).With an increasingly global world and a higher degree of competitiveness, organizations who want to survive the challenges of the market, must be able to adapt themselves quickly to fast changing environments.

There are numerous studies in Portugal on the use of the Internet, but about the maturity of e-business there is nothing. This was the main driver of this work, since they had been taken by Portuguese government some initiatives.

In the last few years several initiatives have been taken and, at the end of 2005, a Technological Plan was launched. This plan aims to mobilize the Portuguese society in order to overcome the modernization challenge the country has been facing in the last years. This plan, included in a broader plan - the National Action Program for Growth and Jobs, 2005-2008 - is based on three main axes:

Knowledge - To qualify the Portuguese for the knowledge society, fostering structural measures which aim at enhancing the average qualification level of the population, implementing a broad and diversified lifelong learning system and mobilizing the Portuguese for the Information Society;

Technology - To overcome the scientific and technological gap, reinforcing public and private scientific and technological competences;

Innovation - To boost innovation, helping the productive chain to get adapted to the challenges of globalization by means of the diffusion and development of new procedures, organizational systems, services and goods.

In 2006 the program "On-the-Spot-Firm" was launched. This program enabled the establishment of certain online companies in less than one hour. The European Commission acknowledged the relevance of this initiative and recently granted Portugal with the European Enterprise Award, on the category "Red Tape Reduction".

The present paper identifies the e-business maturity stage of Portuguese SMEs and large enterprises and makes a correlation between maturity and constraints that are thought to inhibit the development of ebusiness, in each type of enterprises.

\section{Maturity Models}

Maturity models describe the maturing of the use of information systems in organizations. They are a useful framework to describe an organization's current position as well as a range of possible position in the future in terms of their ebusiness maturity.

Even before the emergence of the Internet and the e-business, maturity models were studied by researchers such as Earl (1989), Gibson et al. (1974), Hirschheim et al. (1988), Galliers and Sutherland (1994), Nolan (1973) and Bhabuta (1988). Prananto et al. (2004) mentioned that there have been numerous attempts to develop models of maturity since the emergence and growing importance of IT in organizations. Prananto et al. (2001) considered Nolan to be the first researcher who provided a model to explain the evolution of IS in organizations. This, because Nolan (1973) proposed a model for IS in 1973 which is nowadays one of the best known maturity models. More recently, with the emergence of the Internet and e-commerce, new models were developed which are better adapted to the reality of the e-business. Several stages of growth models were formulated by KPMG (1997), Grant (1999), Earl (2000), McKay et al. (2000), Rayport and Jaworsky (2002), Prananto et al. (2001), Rao et al. (2003) and Chan and Swatman 
(2004). These models describe the various phases involved in moving towards greater sophistication with the respect to the use and management of Information Systems/Information Technology in the new e-commerce environment. Prananto et al. (2003) mentioned that these models aims to capture and describe the various stages involved in the use and management of IT/IS in the new e-business environment by showing the progression of e-business maturity. Thus, organizations are able to determine the level of maturity they achieved by comparing their current situation with the stages of maturity described in the model.

\section{Research Design}

To identify the e-business maturity stage of Portuguese SMEs and large enterprises (during the years 2005 to 2008, for SME and during the years 2005 to 2007 for large enterprises) and to explore the constraints associated to each maturity stage, there was conducted a study which involved an online questionnaire and a sample of 500 SMEs among the best 1000 Portuguese SMEs in 2007, according to the list published in the Exame (2008) magazine and the biggest 1000 (amount of business) Portuguese enterprises, according to the list provided by INE (2007).

For SME 52 valid responses were obtained which corresponds to a $10.8 \%$ response rate, and for large enterprises 138 valid responses were obtained corresponds to a $13.8 \%$ response rate. 208 questionnaires were obtained of large enterprises, but 70 were incomplete (32 do not answer about its maturity stage and 38 do not answer the question about the constraints associated to each maturity stage).

Since Alreck and Settle (1985), Barnett (1991) and Trigo et al (2007) mentioned that the average for this type of questionnaire is between $5-10 \%$, these response rates can be considered as satisfactory.

The questionnaire was structured by thematic groups of questions in order to identify the profile of the questionnaire respondents, to characterize the type of organization, to locate each organization at a certain stage of maturity and to analyze the progress during the last years (20052008). Therefore, in order to explain the progression of e-business in the context of the Portuguese SMEs, the SOG-e (Stages of Growth for e-business) model was used. Prananto et al (2003) defend that as with all other stages of growth models, the SOGe model assumes that a normal progression is from a less mature to an increasing sophistication over time:

- Stage 1: There is no clear direction for the organization's e-business initiatives;

- Stage 2: E-business initiatives are increasingly considered to be an important component of the organization business. However, there is no proper planning and a lack of direction for IS/IT development and implementation;

- Stage 3: E-business initiatives are considered an important component of the organization's business. There is a clear direction for the development of e-business initiatives within the organization. However, e-business development is still very much focused on technology-centric perspective and not influenced by business needs;

- Stage 4: E-business adoption and development is becoming more businessfocused. There is a move towards integration and greater coordination between the components of e-business (e.g. IS/IT and the Internet) and the organization's business processes.

- Stage 5: Integration between traditional business processes and activities and e- 
business processes and activities creates seamless communication and flow of processes within an organization. Ebusiness initiatives aim to provide strategic benefits by building strategic systems;

- Stage 6: E-business is deeply embedded throughout every aspect of the organization. There is a strong integration between the components of e-business and business processes within the organization as well as with those of its suppliers and business partners. E-business initiatives are aimed at creating and maintaining the organization strategic advantage.

\section{Results}

Figure 1 and 2 shows the evolution of ebusiness maturity, between 2005 and 2008 for SME and between 2005 and 2007 for large enterprises.

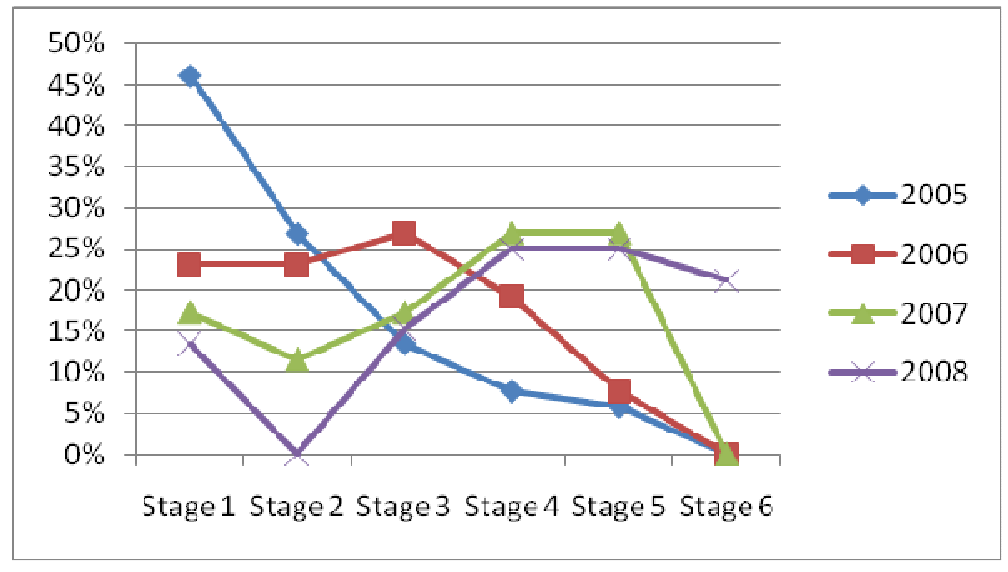

Figure1. Evolution of the e-business maturity in SME

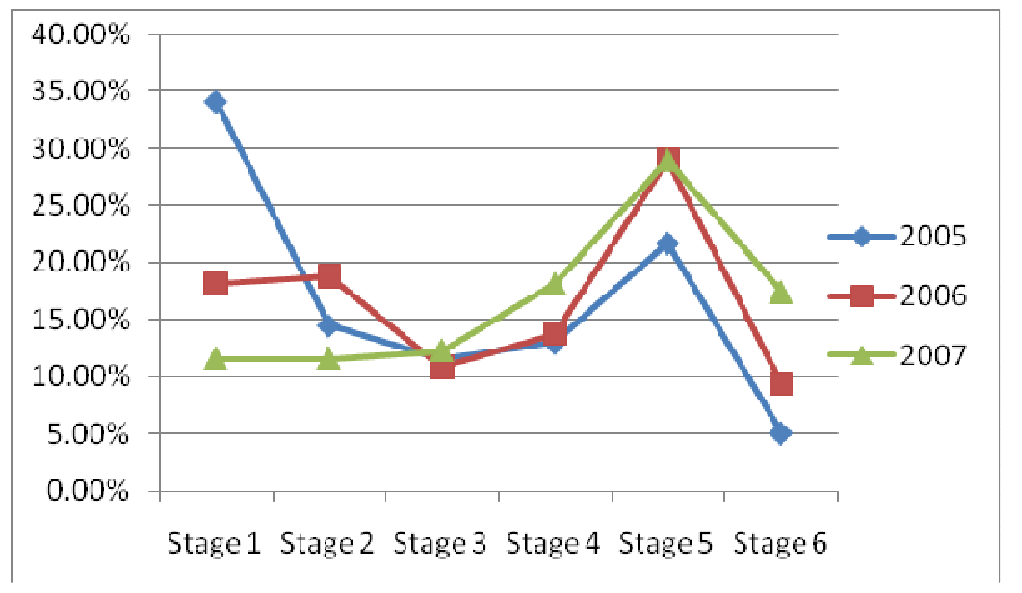

Figure 2. Evolution of the e-business maturity in Large enterprises

Based on the results above, we can conclude that the digital economy is a reality in Portugal, not just for large enterprises but also for Portuguese SMEs, with a clear evolution in the maturity of the e-business (Morais et al, 2009), (Gonçalves et al, 2010).

It is interesting to note that in 2005 the ebusiness for Portuguese companies, 
regardless of size, the e-business was too immature, however, it appears that the evolution has been fairly positive from 2006. Perhaps the initiatives launched by the Portuguese government have been decisive. The fact that few companies are at the final stage of maturity is also understandable because of the dependence on business partners.

In order to evaluate the constraints as associated to e-business evolution, the respondents of both questionnaires were also asked to rate the concerns/problems acting as constraints for the development of their e-business initiatives. In order to explore the relationship between each constraint and the maturity, in each one of the years, we used the Spearman Correlation test. Both the variables are ordinal. The maturity, is an ordinal variable with values from one to six (corresponding to the stage one to six) and each constraint is an ordinal variable with values from one to seven. The results of the test they are shown in table 1 and table 2 . The constraints emerged after having been an exploratory study (Morais, 2009).

Table 1: Spearman Correlation test between each constraint and Maturity $(2005,2006$, 2007 and 2008) of SMEs.

\begin{tabular}{|c|c|c|c|c|c|}
\hline & & $\begin{array}{l}\text { Maturity } \\
2005\end{array}$ & $\begin{array}{l}\text { Maturity } \\
2006\end{array}$ & $\begin{array}{l}\text { Maturity } \\
2007\end{array}$ & $\begin{array}{l}\text { Maturity } \\
2008\end{array}$ \\
\hline \multirow{3}{*}{$\begin{array}{l}\text { Inadequate } \\
\text { Technology }\end{array}$} & $\begin{array}{l}\text { Correlation } \\
\text { coefficient }\end{array}$ &,- 250 & \multirow{2}{*}{$\begin{array}{l}-, 268 \\
, 055\end{array}$} &,$- 347^{*}$ &,$- 278^{*}$ \\
\hline & Sig &, 074 & & 012 & 046 \\
\hline & $\mathrm{N}$ & 52 & 52 & 52 & 52 \\
\hline \multirow{3}{*}{ Cost } & $\begin{array}{l}\text { Correlation } \\
\text { coefficient }\end{array}$ &,- 013 &,- 006 &,- 220 &,- 203 \\
\hline & Sig & ,924 & ,095 & 116 & 149 \\
\hline & $\mathrm{N}$ & 52 & 52 & 52 & 52 \\
\hline \multirow{3}{*}{ Insecurity } & $\begin{array}{l}\text { Correlation } \\
\text { coefficient }\end{array}$ &,- 145 &,- 186 &,- 182 &,- 103 \\
\hline & Sig & 304 & ,186 & 195 & ,468 \\
\hline & $\mathrm{N}$ & 52 & 52 & 52 & 52 \\
\hline \multirow{3}{*}{$\begin{array}{l}\text { Traditional } \\
\text { Business } \\
\text { Partners }\end{array}$} & $\begin{array}{l}\text { Correlation } \\
\text { coefficient }\end{array}$ &,- 054 &,- 039 &,- 070 & -,099 \\
\hline & Sig & ,703 & ,782 & ,624 & 485 \\
\hline & $\mathrm{N}$ & 52 & 52 & 52 & 52 \\
\hline \multirow{3}{*}{$\begin{array}{l}\text { Traditional } \\
\text { Business } \\
\text { Initiatives }\end{array}$} & $\begin{array}{l}\text { Correlation } \\
\text { coefficient }\end{array}$ &,- 121 &,- 123 &,$- 303^{*}$ & -,199 \\
\hline & Sig & ,384 & ,386 & ,029 & 156 \\
\hline & $\mathrm{N}$ & 52 & 52 & 52 & 52 \\
\hline \multirow{2}{*}{$\begin{array}{l}\text { Lack of Senior } \\
\text { Management } \\
\text { Support }\end{array}$} & $\begin{array}{l}\text { Correlation } \\
\text { coefficient }\end{array}$ &,- 058 & \multirow{2}{*}{$\begin{array}{l}-, 052 \\
, 717\end{array}$} &,- 190 &,$- 298^{*}$ \\
\hline & Sig & 683 & & 178 & 032 \\
\hline
\end{tabular}




\begin{tabular}{|c|c|c|c|c|c|}
\hline & $\mathrm{N}$ & 52 & 52 & 52 & 52 \\
\hline \multirow{3}{*}{$\begin{array}{l}\text { Project } \\
\text { Management }\end{array}$} & $\begin{array}{l}\text { Correlation } \\
\text { coefficient }\end{array}$ &,- 141 &,- 132 &,- 222 & -,198 \\
\hline & Sig & ,319 & ,352 & 113 & ,159 \\
\hline & $\mathrm{N}$ & 52 & 52 & 52 & 52 \\
\hline \multirow{3}{*}{$\begin{array}{l}\text { Business } \\
\text { Process } \\
\text { Reengineering }\end{array}$} & $\begin{array}{l}\text { Correlation } \\
\text { coefficient }\end{array}$ &,- 023 &,- 070 &,- 212 &,- 186 \\
\hline & Sig & ,871 & ,622 & 131 & 186 \\
\hline & $\mathrm{N}$ & 52 & 52 & 52 & 52 \\
\hline \multirow{3}{*}{$\begin{array}{l}\text { Business- } \\
\text { Technology } \\
\text { Alignment }\end{array}$} & $\begin{array}{l}\text { Correlation } \\
\text { coefficient }\end{array}$ &,- 098 &,- 146 &,- 244 &,$- 295^{*}$ \\
\hline & Sig & ,490 & ,302 & ,081 & ,034 \\
\hline & $\mathrm{N}$ & 52 & 52 & 52 & 52 \\
\hline \multirow{3}{*}{$\begin{array}{l}\text { Lack of } \\
\text { Human } \\
\text { Resources } \\
\text { Qualified }\end{array}$} & $\begin{array}{l}\text { Correlation } \\
\text { coefficient }\end{array}$ &,- 119 &,- 085 &,- 211 &,- 095 \\
\hline & Sig & ,400 & ,551 & 133 & ,503 \\
\hline & $\mathrm{N}$ & 52 & 52 & 52 & 52 \\
\hline \multirow{3}{*}{$\begin{array}{l}\text { People } \\
\text { Coordination }\end{array}$} & $\begin{array}{l}\text { Correlation } \\
\text { coefficient }\end{array}$ &,- 126 &,- 174 &,- 223 &,- 194 \\
\hline & Sig & ,374 & 218 & 111 & 169 \\
\hline & $\mathrm{N}$ & 52 & 52 & 52 & 52 \\
\hline \multirow{3}{*}{$\begin{array}{l}\text { Resistance to } \\
\text { Change }\end{array}$} & $\begin{array}{l}\text { Correlation } \\
\text { coefficient }\end{array}$ & -,018 &,- 007 &,- 207 &,- 069 \\
\hline & Sig & ,898 & ,963 & ,142 & ,625 \\
\hline & $\mathrm{N}$ & 147 & 52 & 52 & 52 \\
\hline
\end{tabular}

*. Correlation is significant at the 0.05 level (2-tailed).

Table 2: Spearman Correlation test between each constraint and Maturity $(2005,2006$ and 2007) of large enterprises.

\begin{tabular}{lllll}
\hline Constraint & & $\begin{array}{l}\text { Maturity } \\
2005\end{array}$ & $\begin{array}{l}\text { Maturity } \\
2006\end{array}$ & $\begin{array}{l}\text { Maturity } \\
2007\end{array}$ \\
\hline \multirow{2}{*}{$\begin{array}{l}\text { Inadequate } \\
\text { Technology }\end{array}$} & $\begin{array}{l}\text { Correlation } \\
\text { coefficient }\end{array}$ &,$- 280\left(^{* *}\right)$ &,$- 274\left(^{* *}\right)$ &,$- 346\left(^{* *}\right)$ \\
& Sig &, 001 &, 001 &, 000 \\
& $\mathrm{~N}$ & 138 & 138 & 138 \\
\hline \multirow{2}{*}{ Cost } & Correlation &,- 132 &,- 103 &,- 137 \\
& coefficient &, 122 &, 227 &, 109 \\
& Sig & 138 & 138 & 138 \\
\hline \multirow{2}{*}{ Insecurity } & $\mathrm{N}$ &,- 139 &,- 126 &,$- 176\left(^{*}\right)$
\end{tabular}




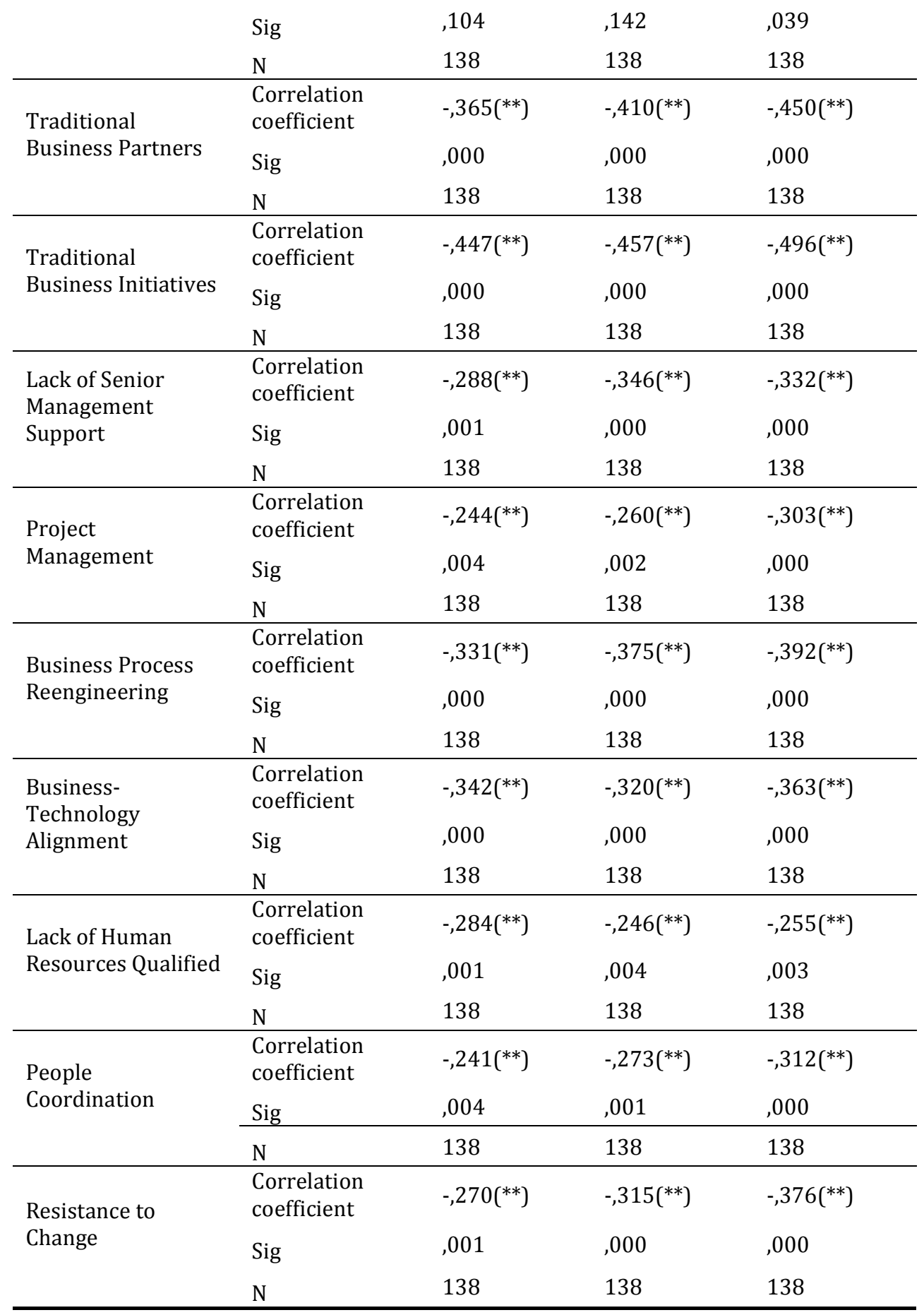

*. Correlation is significant at the 0.05 level (2-tailed).

**. Correlation is significant at the 0.01 level (2-tailed). 
Based on the results of Table 1, it's possible to conclude, for SMEs, that only since 2007 appeared a significant correlation between maturity and some constraints, which can be justified by the near absence of ebusiness in SMEs until 2006, and resulting in a lack of constraints. In 2007 it appears that the constraints that have a significant correlation at $5 \%$ are: the inadequate technology and the incompatibility between traditional business initiatives and $e$ business initiatives. In 2008 the constraints that have a significant correlation at 5\% are: the inadequate technology, the lack of senior management support and the business-technology alignment. The lack of financial resources could be the main cause.

Based on the results above, we can conclude that for large companies there is, for each of the years, a significant correlation $(1 \%)$ between all constraints and the maturity, except of the "cost" and the "insecurity", both without a significant correlation. It should be noted that among the constraints the correlation is significant at $1 \%$ for all cases. It appears that the constraints which the correlation is stronger are constraints that in any way represent change.

\section{Conclusion}

With this study it's possible to conclude, both large and small Portuguese enterprises are sensitive to electronic business, and may even say that the ebusiness is a reality in Portugal. We believe that the existence of incentives may have been central to this development. However, by identifying what the most problematic constraints also realizes the difficulty of reaching the final stage of maturity.

Some constraints are considered problematic, mainly conflict with traditional business and e-business initiatives, conflict with traditional partners and reengineering business processes. The constraints associated to change, are normally the most problematic. Gibbs et al. (2003) conclude that for many European countries, cultural resistance to change and innovation is at the root of resistance to ebusiness. And Portugal, we believe is no exception.

The correlation between the constraints and the maturity is more evident in the large companies, which may be justified by the fact that in SME's may be easier to implement changes. And the most part of the identified constraints are constraints associated with change.

The completion of similar studies in micro enterprises and by activity sectors is also a goal as future work.

\section{References}

Alreck, L and Settle, B. (1985) The survey research handbook, McGraw-Hill Higher Education.

Barnett, V. (19919 Sample survey: Principles and methods, Hodder Arnold.

Bhabuta, L. (1988), "Sustainig Productivity and Competitiveness by Marshalling IT", Paper presented at the Proceedings of the IFIP TC8 Open Conference.

Chan, C., and Swatman, P. (2004), "B2B ECommerce Stages of Growth: the strategic imperatives", Paper presented at the Proceedings of the 37th Annual Hawaii International Conference of System Sciences.

Earl, M. J. (1989) Management Strategies for Information Technology, Prentice Hall. 
Earl, M. J. (2000), "Evolving the EBusiness", Business Strategy Review (11).

European Comission (2008). The European E-business Report 2008: the impact of ICT on and e-business on firms, sectors and economy.

Exame (2008), Listagem das 1000 melhores PME portuguesas. Retrieved November 6, 2008, from: http://exame.edimpresa.viatecla.pt/especi aisdetalhe.aspx?channelid=4E23AD7D3F76-46F4-8E5D4FD7B4BB829C\&contentid=DC1E87707256-4833-92CF-3B2C5A6B1221

Galliers, R. D., and Sutherland, A. R. (1994), "Information Systems Management and Strategy Formulations: Applying and Extending the 'Stages of Growth' Concept", in Strategic Information Management: Challenges and Strategies in Managing Information Systems: ButterworthHeinemann Ltd Oxford.

Gibbs, J., Kraemer, K., Dedrick, J. (2003), "Environment and Policy Factors Shaping Global E-Commerce Diffusion: A CrossCountry Comparison". The Information Society, 19 (1): 5-18.

Gibson C. F. and R. L. Nolan (1974), "Managing the Four Stages of EDP Growth". Harvard Business Review, 52 (1), 76-88.

Gonçalves, R., Santos, S. and E. Paulo Morais (2010), "E-Business maturity and information technology in Portuguese SMEs". Communications of the IBIMA, Vol. 2010, Article ID 303855, ISSN: 1943-7765.
Grant S., (1999), "E-Commerce for Small Businesses, Innovation Through Electronic Commerce". Proceedings of the 2nd International Conference. Manchester, England.

Hirschheim, R., Earl, M., Feeny, D., and Lockett, M. (1998) "An Exploration into the Management of the Information Systems Function: Key Issues and an Evolutionary Model", Paper presented at the Proceedings of the IFIP TC8 Open Conference.

INE, National Institute of Statistics of Portugal, October 2007

KPMJ (1997). Electronic Commerce Research Report, London, UK.

McKay, J., Prananto A., and Marshall P. (2000), "E-business Maturity: The SOG-e Model", Paper presented at the Proceedings of the 11th Australasian Conference on Information Systems (ACIS).

Morais, E. Maturidade do Negócio Electrónico - Constrangimentos associados à sua evolução (2009), Doctoral dissertation, University of Trás-os-Montes e Alto Douro, Portugal, 2009.

Nolan, R. L. (1973), Managing the Computer Resource: A Stage Hypothesis. Communications of ACM. 16 (7), 339-406.

Prananto A., McKay J., and Marshall P. (2001), "Frameworks to Support EBusiness Strategy", Paper presented at the Global CoOperation in the New Millennium: The 9th European Conference on Information Systems. 
Prananto, A., McKay, J., and Marshall, P. (2003), "A Study of the Progression of EBusiness Maturity in Australian SMEs: Some Evidence of the Applicability of the Stages of Growth for E-Business Model", Paper presented at the PACIS 2003 Proceedings.

Prananto, A., McKay, J., and Marshall, P. (2004), "Lessons learned from analysing ebusiness progression using a stage model in Australian Small Medium Enterprises (SMEs)", ACIS 2004 Proceedings.

Rao, S., Metts, G., and Monge, A. (2003), "Electronic Commerce Development in
Small and Medium Sized Enterprises: A stage Model and its Implications," Business Process Management Journal 9 (1).

Rayport, J., and Jaworsky, B. (2002) Introduction to E-Commerce: McGraw-Hill.

Trigo, A., Varajão, J., Figueiredo, N. and Barroso, J. (2007), Information Systems and Technology Adoption by the Portuguese Large Companies", Proceedings of European and Mediterranean Conference on Information Systems 2007 (EMCIS2007), June 24-26 2007, Polytechnic University of Valencia, Spain. 